\title{
SDH Activity in Heavy Metal-treated Malpighian Tubules of Triatoma infestans Klug (Hemiptera, Reduviidae)
}

\author{
F. S. Kubrusly and M. L. S. Mello \\ Department of Cell Biology, Institute of Biology, UNICAMP, 13081 \\ Campinas (SP), Brazil
}

Accepted August 13, 1990

The localization of mitochondria in the Malpighian tubules of Triatoma infestans Klug, which varies preferentially as a function of the organ region and of its physiology, has been established ultrastructurally (Mello and Dolder 1977). Cytochemical detection of succinic dehydrogenase (SDH) activity using a rather simple technique at the light microscopy level (Wegmann and Tordet-Caridroit 1960) has confirmed the preferential distribution of the mitochondria in the apical region of the distal cells and basal region of the proximal cells of the Malpighian tubules of this insect species (Azeredo-Oliveira and Mello 1985).

Heavy metals are known to affect some cell enzyme activities in the Malpighian tubules of $T$. infestans, including those of $\mathrm{Mg}^{2+}$-dependent ATPases and acid phosphatases (Kubrusly 1984). It is suspected that mitochondrial SDH activity may also be disturbed by these agents. Furthermore, if the cytoskeleton elements of the Malpighian tubule cells were affected by heavy metals (Mello and Dolder 1977), the distribution of mitochondria along the cells may also be affected (Smith et al. 1975, Birky Jr. 1983).

Considering that a cytochemical investigation of SDH activity may clarify both questions. this analysis was carried out on the Malpighian tubules of $T$. infestans subjected to treatment with $\mathrm{Cu}^{2+}$ and $\mathrm{Hg}^{2+}$ ions.

\section{Material and methods}

Unfixed Malpighian tubules removed from 5th instar nymphs of Triatoma infestans Klug (Hemiptera, Reduviidae) were used $2 \mathrm{~h}$ after the injection of $0.05 \mathrm{ml}$ of $10^{-5} \mathrm{M}(2.5 \mathrm{ppm})$ and $2 \times 10^{-5} \mathrm{M} \mathrm{CuSO}_{4}$ and $1.56 \times 10^{-4} \mathrm{M}(40 \mathrm{ppm}) \mathrm{CH}_{3} \mathrm{HgCl}_{2}$ solutions. Controls were injected with an equal volume of Ringer's solution or distilled water. Two specimens were used for each experimental condition.

The concentrations of $\mathrm{CuSO}_{4}$ used were those known to be toxic in other cell systems (Sullivan and Cheng 1975) and even to destabilize microtubules (Mello and Dolder 1987) and increase $\mathrm{Mg}^{2+}$-dependent ATPase activity (Kubrusly 1984) in the Malpighian tubule cells of $T$. infestans. The $\mathrm{CH}_{3} \mathrm{HgCl}_{2}$ concentration was that which induces an increase in acid phosphatase activity in $T$. infestans cells (Kubrusly 1984).

In a parallel assay, none of 60 specimens of $T$. infestans tested were found to have died $2 \mathrm{~h}$ after the injection of $\mathrm{CuSO}_{4}$ or $\mathrm{CH}_{3} \mathrm{HgCl}_{2}$.

The material was subjected to the method of Nachlas and coworkers for the detection of SDH activity, modified by Wegmann and Tordet-Caridroit (1960). Tubules incubated in the absence of substrate were used as a control of the reaction.

\footnotetext{
${ }^{1}$ Reprint requests to Dr. M. L. S. Mello
} 


\section{Results}

SDH activity detected by the visualization of microcrystalline deposits of bluish-violet formazan was observed in the cytoplasm of the Malpighian tubule cells of both control and experimental insect specimens.

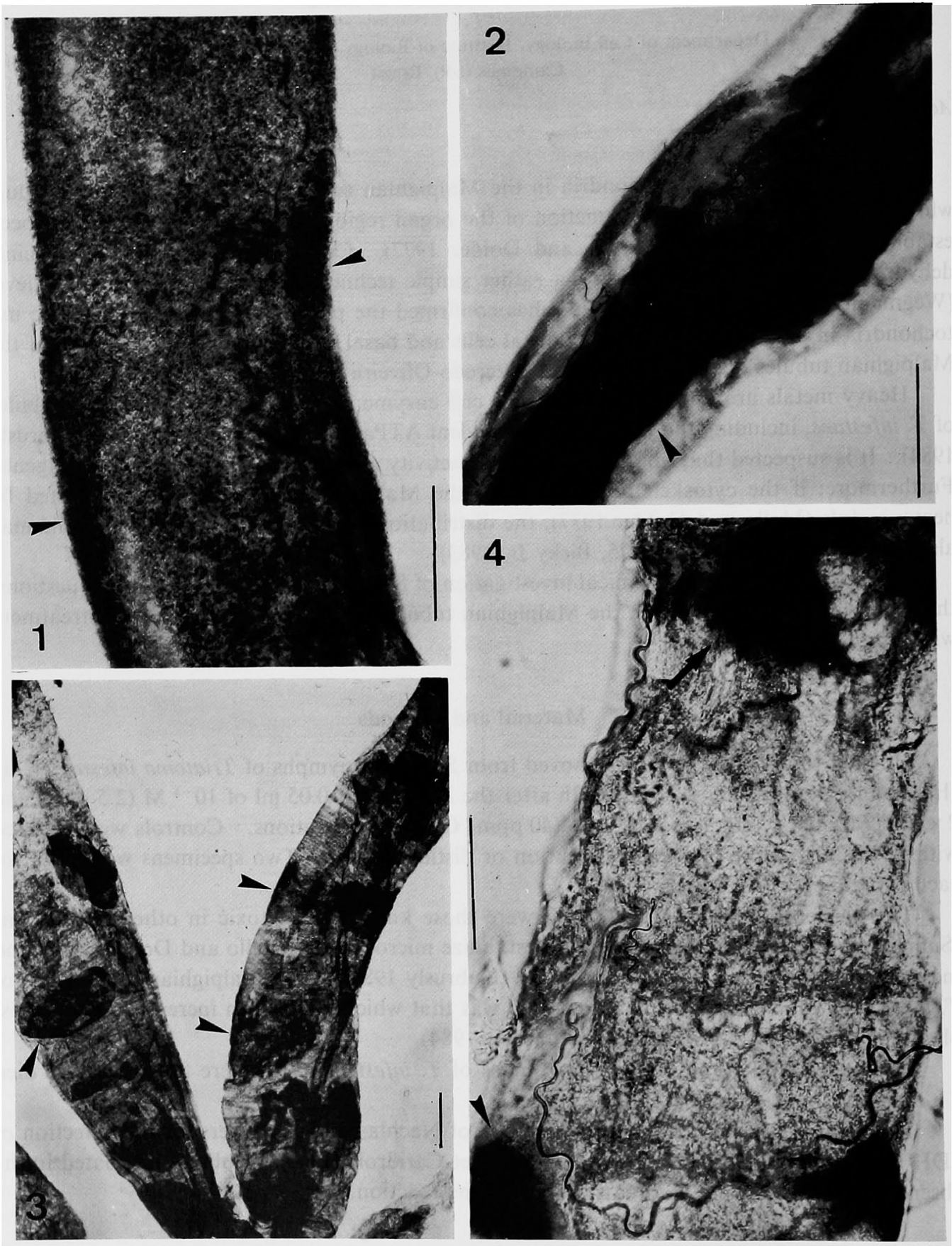

Figs. 1-4. SDH acitvity in the Malpighian tubule cells of $T$. infestans. The arrows indicate regions of intense reaction in the proximal (1) and distal (2-4) regions of the tubules. Insects were treated with $10^{-5} \mathrm{M}(1,4)$ and $2 \times 10^{-5} \mathrm{M}(2,3) \mathrm{CuSO}_{4}$ solutions. $\mathrm{Bar}=50 \mu \mathrm{m}$. 
Controls exhibited higher SDH activity in the apical region of the distal cells and in the basal region of the proximal cells, in agreement with previous studies reporting preferential mitochondria localization as a function of the Malpighian tubule regions in T. infestans (Mello and Dolder 1977, Azeredo-Oliveira and Mello 1985).

The same pattern of intensity and distribution of the reaction due to the SDH activity was detected in part of the distal and proximal cells of the tubules dissected from the insects treated with the metal ions (Figs. 1 and 2). However, other cells, especially those in the distal region of the tubules, showed a positive reaction only in their middle parts, exhibiting dense and irregularly-shaped formazan deposits (Figs. 3 and 4). In contrast, part of the cells of the distal region and most cells of the proximal region exhibited a very faint reaction not predominantly concentrated in a specific cellular zone (Fig. 4).

No striking differences between the effects promoted by $\mathrm{Cu}^{2+}$ and $\mathrm{Hg}^{2+}$ ions could be detected.

The above-mentioned characteristics of the reaction were absent when the substrate was omitted from the incubation medium.

\section{Discussion}

The results showed that the SDH activity of the Malpighian tubule cells of $T$. infestans is not homogeneously affected by metal ion treatment. There are distal and proximal cells in the organ which continue to present the same intensity of enzyme activity in the same places as in control cells. However, a decrease in SDH activity was also verified, especially in the proximal cells, which under ordinary conditions are known to exhibit mitochondria situated in the basal cellular region (Mello and Dolder 1977).

As regards the cells which were unaffected by the metal ions, they may possibly have resistance mechanisms for coping with mercury and copper ions under the experimental conditions to which they were subjected. Even in terms of insect survival, resistance to copper and mercury toxicity varies among individuals in a given population (Kubrusly 1984). Special mechanisms of resistance have also been reported to have evolved in certain free-living bacterial cells (Silver and Misra 1984).

In the cells with decreased SDH activity a blockade of the citric acid cycle with accumulation of acetyl CoA may have occurred, and the efficiency of the electron-transport chain may have been reduced (Rawn 1989).

The displacement of the enzyme reaction products from the apical cellular zone to the middle of the cells in part of the distal region of the tubules is suggested to indicate a change in the spatial distribution of the mitochondria. This phenomenon may well mean that the microtubules and other cytoskeleton elements, which are assumed to hold mitochondria in fixed positions (Smith et al. 1975, Birky Jr. 1983), were affected by the $\mathrm{Cu}^{2+}$ and $\mathrm{Hg}^{2+}$ ions. $\mathrm{Cu}^{2+}$ ions have been reported to disorganize microtubules in several cell systems, including the Malpighian tubule cells of $T$. infestans (Mello and Dolder 1987). However, no mention has been made of a similar action promoted by $\mathrm{Hg}^{2+}$ ions.

Heavy metal pollutants, such as copper sulphate and methylmercury chloride are thus to be considered as potential candidates for a direct effect on mitochondrial performance and for an indirect effect on other cell functions in special cellular domains, which require a specific mitochondrial spatial distribution.

\section{Summary}

A variable effect of $\mathrm{Cu}^{2+}$ and $\mathrm{Hg}^{2+}$ ions on the intensity and localization of the SDH 
activity was cytochemically detected in the Malpighian tubule cells of the blood-sucking insect, Triatoma infestans. Unaffected and decreased enzyme activities as well as a change in the spatial distribution of mitochondria were detected on the basis of the cytochemical localization of the enzyme. It is assumed that these metal ions could affect not only the mitochondrial performance but also other cell functions which require a specific mitochondrial distribution.

\section{Acknowledgments}

The authors are indebted to Dr. N. Ballatori for kindly supplying the $\mathrm{CH}_{3} \mathrm{HgCl}_{2}$, to $\mathrm{Dr}$. A. L. Cortelazzo for valuable discussion, and to Mr. A. N. Ferraz Filho for providing the insects. One of the authors (FSK) is indebted to $\mathrm{CNPq} / \mathrm{Brazil}$ for financial support.

\section{References}

Azeredo-Oliveira, M. T. V. and Mello, M. L. S. 1985. Succinate dehydrogenase (SDH) activity in Malpighian tubules of Triatoma infestans Klug (Insecta, Heteroptera). Zool. Jb. Anat. 113: 493-496.

Birky Jr., C. W. 1983. The partitioning of cytoplasmic organelles at cell division. Int. Rev. Cytol. (Suppl.) 15: $49-89$.

Kubrusly, F.S. 1984. Ação de cobre e mercúrio sobre estrutura nuclear e atividade de alguns sistemas enzimaticos em Triatoma infestans Klug. Master's thesis. UNICAMP, Campinas, pp. 71.

Mello, M. L.S. and Dolder, H. 1977. Fine structure of the Malpighian tubes in the blood-sucking insect, Triatoma infestans Klug. Protoplasma 93: 275-288.

- and Dolder, M. A. H. 1987. Axopodal structures in the Malpighian tubules of blood-sucking hemipterans. Cytologia 52: 425-431.

Rawn, J. D. 1989 . Biochemistry. Neil Patterson Publ., Burlington.

Silver, S. and Misra, T. K. 1984. Bacterial transformations of and resistances to heavy metals. In: Genetic Control of Environmental Pollutants. G. S. Omen and A. Hollaender (ed.). Plenum Press, New York and London, pp. 23-46.

Smith, D. S., Järlfors, U. and Cameron, B. F. 1975. Morphological evidence for the participation of microtubules in axonal transport. Ann. N. Y. Acad. Sci. 253: 472-506.

Sullivan, J. T. and Cheng, T. C. 1975 . Heavy metal toxicity to Biomphalaria glabrata (Mollusca: Pulmonata). Ann. N. Y. Acad. Sci. 266 : 437-444.

Wegmann, R. and Tordet-Caridroit, C. 1960. Histochemical demonstration of succinic dehydrogenase by specific inhibition and activation. J. Histochem. Cytochem. 8: 348-349. 